\title{
Financial Technology (Fintech) Dalam Inklusi Keuangan Nasional di Masa Pandemi Covid-19
}

\author{
Ratnawaty Marginingsih \\ Universitas Bina Sarana Informatika \\ e-mail: ratnawaty.rmg@bsi.ac.id

\begin{tabular}{ccc}
\hline Diterima & Direvisi & Disetujui \\
$15-01-2021$ & $16-03-2021$ & $18-03-2021$ \\
\hline
\end{tabular}

\begin{abstract}
Abstrak - Pandemi Covid-19 berdampak pada perlambatan ekonomi nasional, Financial Technology (Fintech) memiliki potensi mengambil peran dalam upaya pemulihan ekonomi. Dampak pandemi covid-19 yang semakin meluas sektor Financial Technology (Fintech) memiliki peran penting untuk meningkatkan inklusi finansial dan kesejahteraan masyarakat. Metode penelitian yang digunakan untuk penulisan ini adalah teknik analisis deskriptif kualitatif. Hasil penelitian menujukkan keberadaan Financial Technology (Fintech) memiliki dampak positif dimasa pandemi covid-19. Kontribusi Fintech telah banyak membantu masyarakat yang masih belum terlayani lembaga keuangan formal dalam melakukan transaksi keuangan sesuai dengan kebutuhannya. Pemulihan ekonomi nasional dan peningkatan penerimaan negara dimasa pandemi dapat dilakukan dengan dukungan penguatan regulasi terhadap pertumbuhan Fintech yang inklusif dan berkesinambungan yang memiliki potensi sebagai faktor pemicu lompatan yang sangat besar bagi industri pembayaran layanan keuangan digital.
\end{abstract}

Kata Kunci: Financial Technology, Inklusi Keuangan, Ekonomi Nasional

Abstract - The Covid-19 pandemic has an impact on the national economic slowdown, Financial Technology (Fintech) has the potential to play a role in economic recovery efforts. The impact of the Covid-19 pandemic which is increasingly widespread in the Financial Technology (Fintech) sector has an important role to play in increasing financial inclusion and public welfare. The research method used for this writing is a qualitative descriptive analysis technique. The research results show that the existence of Financial Technology (Fintech) has a positive impact during the Covid-19 pandemic. Fintech's contribution has helped many people who are still not served by formal financial institutions in carrying out financial transactions according to their needs. National economic recovery and increased state revenue during the pandemic can be carried out with the support of strengthening regulations for inclusive and sustainable Fintech growth which has the potential to trigger a huge leap for the digital financial service payment industry.

Keywords: Financial Technology, Financial Inclusion, National Economy

\section{PENDAHULUAN}

Kondisi perekonomian Indonesia yang tertekan dan penuh tantangan akibat pandemi virus corona Covid-19, inklusi keuangan memiliki peranan penting bagi perekonomian. Keterbukaan terhadap akses keuangan atau inklusi keuangan bagi masyarakat menjadi salah satu kunci pembangunan dalam era digitalisasi saat ini. Strategi keuangan inklusif bukan merupakan sebuah inisiatif yang terisolasi. Sehingga keterlibatan dalam hal keuangan inklusif tidak hanya terkait dengan tugas Bank Indonesia sebagai bank sentral, namun juga para regulator, kementerian dan lembaga lainnya dalam upaya pemberian pelayanan keuangan kepada masyarakat luas. Melalui strategi nasional dalam keuangan inklusif diharapkan kolaborasi antar lembaga pemerintah dan pemangku kepentingan tercipta secara baik dan terstruktur. (Bank Indonesia, 2020)

Perlambatan ekonomi pada masa pandemi saat ini, Fintech memiliki potensi untuk mengambil peran dalam proses pemulihan ekonomi. Karakteristik Fintech yang memiliki sifat lowtouch economy, customer-based, berbasis social capital, penggunaan data science serta digerakkan oleh profesional muda, perkembangan Fintech pada masa pandemi masih positif.

Peran Fintech untuk meningkatkan inklusi keuangan juga tercermin dalam beberapa karakter dasar Fintech yang dapat dijabarkan sebagai berikut: pertama, meningkatkan akses dan desentralisasi sistem keuangan, dimana kemajuan teknologi yang digunakan memungkinkan inklusi baik komunitas individu maupun UMKM yang tidak bankable untuk dapat berperan sebagai penyedia dan pengguna dana dalam sistem keuangan; kedua, meningkatkan 
transparansi, akuntabilitas dan kolaborasi lintas sektor, dimana teknologi dapat menjadi penyedia transparansi, penelusuran, pertanggungjawaban, dan pembagian informasi yang lebih besar kepada pemerintah, masyarakat dan swasta untuk saling bekerja sama; dan ketiga, biaya yang lebih rendah melalui peningkatan efisiensi, kecepatan dan otomatisasi. Karakter dari Fintech inilah yang dapat menjangkau seluruh lapisan masyarakat agar dapat terakses dengan layanan keuangan formal (Pratiwi, 2018)

Berdasarkan data Statistik OJK per Juli 2020, akumulasi penyaluran pinjaman tahun 2020 (Januari hingga Juli) melalui Fintech mencapai sebesar Rp35 Triliun dengan pertumbuhan per tahun mencapai sebesar 135 persen (Juli, 2020, year-on-year). Hal ini menujukkan minat masyarakat untuk melakukan pinjaman melalui Fintech masih tumbuh meskipun ada pandemi (Otoritas Jasa Keuangan, 2020)

Keberadaan Fintech saat ini semakin relevan sebagai sarana untuk mendalami pasar keuangan di Indonesia, khususnya kelompok masyarakat yang selama ini masih belum terlayani lembaga keuangan formal. Peran Fintech dalam pemerataan sektor ekonomi khususnya UMKM, juga terlihat dari peningkatan persebaran pinjaman Fintech ke wilayah di luar Jawa yang naik sebesar $107 \%$ (year-on-year) (INDEF, 2019)

Nilai akumulasi penyaluran pinjaman dari Fintech lending di Indonesia mencapai Rp 88,4 triliun atau meningkat hampir $240 \%$ Adapaun akumulasi penyaluran pinjaman Fintech Lending di Indoensia dapat dilihat pada gambar berikut ini:

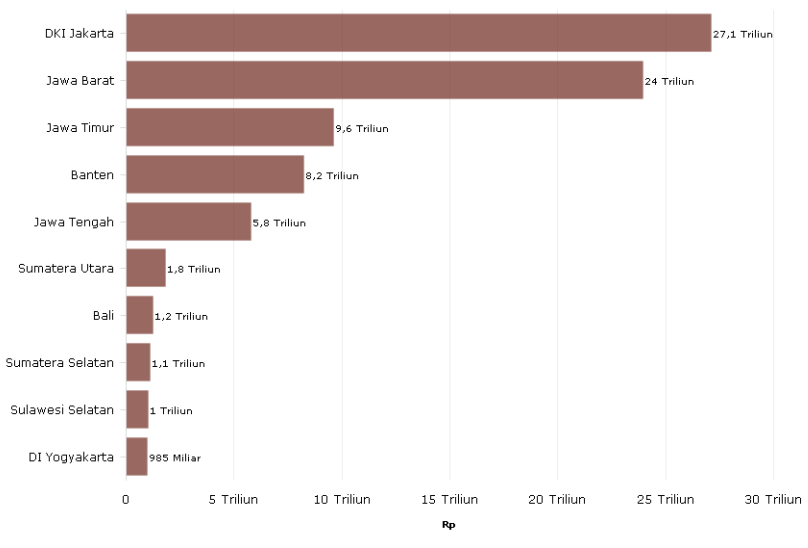

Sumber: OJK dalam Katadata (2020)

Gambar 1

Nilai Akumulasi Penyaluran Pinjaman dari Fintech Lending di Indonesia

Berdasarkan gambar diatas dapat dilihat bahwa secara tahunan. DKI Jakarta dan Jawa Barat menjadi provinsi dengan penyaluran dana Fintech terbesar, yakni sebesar Rp 27,1 triliun dan Rp 24 triliun. Penyaluran pinjaman dalam jumlah besar juga terjadi di provinsi Jawa Timur (Rp 9,6 triliun), Banten (Rp 8,2 triliun), dan Jawa Tengah ( $R p$ 5,8 triliun).
Kemudian, penyaluran dengan kisaran Rp 1 triliun ada di Sumatera Utara, Bali, Sumatera Selatan, Sulawesi Selatan, dan DI Yogyakarta (Katadata, 2020)

Sektor Fintech menjadi strategi yang sangat penting untuk memperluas inklusi keuangan serta meningkatkan kesejahteraan masyarakat. Keberadaan Fintech semakin diuntungkan dengan masifnya penggunaan smartphone oleh masyarakat, bahkan hingga daerah pedesaan, menjadi sarana penghubung dan solusi bagi masyarakat yang selama ini sulit dijangkau oleh lembaga keuangan formal. Lewat penggunaan smartphone, masyarakat dapat menggunakan layanan finansial dengan mudah untuk memenuhi kebutuhannya atau menjaga keberlanjutan bisnisnya dalam upaya pemulihan ekonomi nasional yang mengalami perlambatan imbas meluasnya dampak pandemi covid-19.

\section{Financial Technology (Fintech)}

Industri Financial Technology (Fintech) merupakan salah satu inovasi layanan jasa keuangan yang mulai populer di era digital sekarang ini dan teknologi dengan konsep digitalisasi pembayaran menjadi salah satu sektor dalam industri Fintech yang paling berkembang di Indonesia. Dalam hal ini sektor Fintech paling diharapkan oleh pemerintah dan masyarakat untuk mendorong dan meningkatkan jumlah masyarakat yang memiliki akses untuk dapat menggunakan layanan keuangan (Muzdalifa, Rahma, \& Novalia, 2018)

Bank Indonesia memberikan definisi mengenai Financial Technology (Teknologi Finansial). yang diatur dan tertuang pada Pasal 1 Angka 1 Peraturan Bank Indonesia Nomor 19/12/PBI/2017. Tentang Penyelenggaraan Teknologi Finansial menyatakan bahwa Teknologi Finansial adalah pengguna teknologi dalam sistem pada bidang keuangan yang menghasilkan produkproduk layanan, teknologi, dan atau model bisnis baru serta dapat berdampak pada kondisi stabilitas moneter, stabilitas pada sistem keuangan, dan atau efisiensi, kelancaran, keamanan serta kehandalan sistem pembayaran.

Sedangkan menurut Financial Stability Board dalam (Nizar, 2017) mendefinisikan Fintech sebagai suatu bentuk inovasi teknologi dalam layanan keuangan yang dapat menghasilkan model-model bisnis, aplikasi, proses atau produk-produk dengan efek material yang terkait dengan penyediaan jasa layanan leuangan.

Berdasarkan pengertian diatas dapat disimpulkan bahwa Financial Technology (Fintech) merupakan suatu inovasi pada industri jasa keuangan yang memanfaatkan penggunaan teknologi. yang dapat memfasilitasi masyarakat untuk melakukan proses teransaksi keuangan. 


\section{Klasifikasi Financial Technology (Fintech)}

Financial Technology (Fintech) memiliki ragam layanan dan produk yang bisa dimanfaatkan oleh masyarakat. Klasifikasi Fintech berdasarkan Bank Indonesia, terbagi menjadi 4 jenis (Maulida, 2019), yakni:

1 Peer-to-Peer (P2P) Lending dan Crowdfunding $\mathrm{P} 2 \mathrm{P}$ lending dan crowdfunding, Fintech satu ini seperti marketplace finansial. Platform ini mampu mempertemukan pihak yang memerlukan dana dengan pihak yang dapat memberi dana sebagai modal ataupun investasi. Peer-to-peer lending atau P2P lending dapat pula diartikan sebagai layanan peminjaman dana pada masyarakat. Dana tersebit dapat berasal dari masyarakat itu sendiri maupun dari perusahaan yang membangun platform tersebut.

2. Manajemen Risiko Investasi

Fintech jenis ini dapat digunakan untuk melakukan pantauan pada kondisi keuangan dan juga melakukan perencanaan keuangan dengan lebih mudah dan praktis. Jenis manajemen risiko investasi yang satu ini biasanya hadir dan bisa diakses dengan menggunakan smartphone, dimana hanya perlu memberikan data-data yang dibutuhkan untuk bisa mengontrol keuangan.

3. Payment, Clearing, dan Settlement

Fintech jenis ini ada beberapa startup finansial yang memberikan penyedian berupa payment gateaway atau dompet digital Fintech payment gateway menghubungkan bisnis e-commerce dengan berbagai bank sehingga penjual dan pembeli dapat melakukan transaksi kedua produk tersebut masih masuk dalam kategori Fintech ini.

4. Market Aggregator

Hadirya Fintech ini mengacu pada portal yang mengumpulkan berbagai jenis informasi terkait sektor keuangan untuk disajikan kepada penggunanya. Biasanya Fintech jenis ini mempunyai cakupan informasi terkait keuangan, tips, kartu kredit, dan investasi keuangan lainnya. Hadirnya Fintech jenis ini, diharapkan dapat menyerap banyak informasi sebelum melakukan pengambilan keputusan terkait keuangan.

\section{Inklusi Keuangan}

Inklusi keuangan saat ini selalu menjadi bahasan penting pada taraf global maupun nasional. Salah satu upaya untuk meningkatkan pertumbuhan ekonomi serta mengurangi angka kemiskinan, program keuangan inklusif dirasa perlu dilakukan untuk mewujudkan sistem keuangan yang lebih mudah diakses oleh masyarakat. Inklusi keuangan dapat dikatakan sebagai sebuah proses untuk menjamin kemudahan akses, ketersedian dan penggunaan sistem keuangan formal oleh seluruh pelaku ekonomi. Dalam inklusi keuangan tersedia berbagai jasa keuangan seperti tabungan, perkreditan, asuransi, dan pembayaran pada tingkat harga yang mampu dibayar oleh seluruh pelaku ekonomi, terutama pelaku ekonomi yang memiliki pendapatan rendah (Okaro, 2016)

Menurut Bank Indonesia istilah inklusi keuangan adalah upaya dalam melakukan penghapusan segala bentuk hambatan yang ada terhadap akses layanan keuangan masyarakat dengan memanfaatkan lembaga keuangan formal atau perbankan. Tujuan inklusi keuangan yaitu untuk mencapai pertumbuhan ekonomi melalui pemerataan pendapatan, pengentasan kemiskinan serta stabilitas sistem keuangan (Awanti, 2017)

Sedangkan menurut Reserve Bank of India dalam (Anwar \& Amri, 2017) inklusi keuangan adalah sebuah proses untuk menjamin akses terhadap produk dan jasa keuangan yang dibutuhkan oleh setiap bagian masyarakat baik masyarakat umum ataupun masyarakat yang rentan seperti masyarakat berpendapatan rendah pada tingkat harga yang mampu dibayar dengan cara yang adil dan transparan

Berdasarkan pengertian diatas dapat disimpulkan bahwa inklusi keuangan adalah merupakan suatu kondisi dimana setiap orang dimungkinkan untuk bisa mempunyai akses dalam memanfaatkan produk atau layanan jasa keuangan sesuai dengan kebutuhannya.

\section{Tujuan dan Manfaat Inklusi Keuangan}

Berdasarkan Peraturan Otoritas Jasa Keuangan Nomor 76/POJK.07/2016, setidaknya terdapat empat tujuan inklusi keuangan. Pertama adalah untuk meningkatkan akses masyarakat pada suatu produk, lembaga atau layanan jasa keuangan. Kedua, untuk menyediakan berbagai produk atau layanan jasa keuangan PUJK (Pelaku Usaha Jasa Keuangan). Ketiga, untuk meningkatkan produk atau layanan jasa keuangan yang bisa disesuaikan dengan kemampuan dan keperluan masyarakat luas. Terakhir, untuk melakukan peningkatan kualitas produk serta layanan jasa keuangan.

Sedangkan manfaat dari keuangan inklusi menurut Bank Indonesia adalah sebagai berikut:

1. Mampu meningkatkan efisiensi ekonomi.

2. Mendukung stabilitas sistem keuangan.

3. Mengurangi terjadinya shadow banking atau irresponsible finance.

4. Mendukung pendalaman pasar keuangan

5. Memberikan potensi pasar baru bagi perbankan.

6. Mendukung peningkatan Human Development Index (HDI) Indonesia.

7. Berkontribusi positif terhadap tingkat pertumbuhan ekonomi lokal dan nasional yang berkelanjutan

8. Mengurangi tingkat kesenjangan dan rigiditas low income trap, sehingga dapat meningkatkan kesejahteraan masyarakat yang pada akhirnya berujung pada penurunan tingkat kemiskinan. 


\section{METODE PENELITIAN}

Metode penelitian yang digunakan pada penelitian ini adalah teknik analisis deskriptif kualitatif, dimana prosedur penelitian yang dihasilkan berupa kata-kata tertulis atau lisan dari orang-orang dan perilaku yang dapat diamati akan memberikan gambaran hasil penelitian Teknik pengumpulan data menggunakan pendekatan studi literatur. Literatur yang digunakan untuk acuan meliputi buku teks, artikel media massa, dan penelusuran literatur online yang berkaitan dengan penelitian ini.

\section{HASIL DAN PEMBAHASAN}

\section{A. Penyaluran Fintech Lending Sektor Ekonomi}

Tabel 1. Dampak Fintech Peer-to-Peer (P2P) Lending Terhadap Pertumbuhan Ekonomi

\begin{tabular}{|c|c|c|c|c|}
\hline \multirow[b]{2}{*}{ Produk } & \multicolumn{2}{|c|}{2018} & \multicolumn{2}{|c|}{2019} \\
\hline & $\begin{array}{c}\text { Penambahan } \\
\text { Nilai } \\
\text { (juta rupiah) }\end{array}$ & $\begin{array}{l}\text { Perubahan } \\
\quad(\%)\end{array}$ & $\begin{array}{c}\text { Penambahan } \\
\text { Nilai } \\
\text { (juta rupiah) }\end{array}$ & $\begin{array}{l}\text { Perubahan } \\
\quad(\%)\end{array}$ \\
\hline $\begin{array}{l}\text { Pertanian, Kehutanan, dan } \\
\text { Perikanan }\end{array}$ & $276,609.78$ & 0.023 & $49,152.89$ & 0.004 \\
\hline Pertambangan dan Penggalian & $288,885.21$ & 0.031 & $51,459.65$ & 0.005 \\
\hline Industri Pengolahan & $469,356.96$ & 0.011 & $79,333.83$ & 0.002 \\
\hline Pengadaan Listrik, Gas & $786,101.99$ & 0.254 & $183,201.18$ & 0.059 \\
\hline $\begin{array}{l}\text { Pengadaan Air, Pengelolaan } \\
\text { Sampah dan Limbah serta Daur } \\
\text { Ulang }\end{array}$ & $720,309.86$ & 3.025 & $103,815.98$ & 0.436 \\
\hline Konstruksi & $138,914.00$ & 0.008 & $21,270.65$ & 0.001 \\
\hline $\begin{array}{l}\text { Perdagangan Mobil dan Sepeda } \\
\text { Motor serta Reparasi }\end{array}$ & $417,559.79$ & 0.161 & $69,125.08$ & 0.027 \\
\hline $\begin{array}{l}\text { Perdagangan selain Mobil dan } \\
\text { Sepeda Motor }\end{array}$ & $7,220,918.52$ & 0.650 & $55,507.30$ & 0.005 \\
\hline Transportasi dan Pergudangan & $648,940.97$ & 0.118 & $104,827.09$ & 0.019 \\
\hline $\begin{array}{l}\text { Penyediaan Akomodasi dan Makan } \\
\text { Minum }\end{array}$ & $273,988.89$ & 0.062 & $67,283.83$ & 0.015 \\
\hline Informasi dan Komunikasi & $811,886.26$ & 0.198 & $492,964.58$ & 0.121 \\
\hline Jasa Keuangan Perbankan & $1,577,659.96$ & 0.820 & $1,949,987.80$ & 1.013 \\
\hline Jasa asuransi & $1,924,451.90$ & 3.489 & $1,512,957.27$ & 2.743 \\
\hline Jasa Dana Pensiun & $905,046.74$ & 6.954 & $3,323,997.09$ & 25.539 \\
\hline Jasa Lembaga Keuangan Lainnya & $7,403,789.98$ & 10.217 & $49,347,376.41$ & 68.098 \\
\hline Jasa Real Estate & $576,192.78$ & 0.234 & $76,742.41$ & 0.031 \\
\hline Jasa Perusahaan & $1,210,475.40$ & 0.596 & $598,521.38$ & 0.295 \\
\hline Jasa Pemerintahan Umum & $54,120.70$ & 0.013 & $51,641.58$ & 0.012 \\
\hline Jasa Pendidikan & $42,466.00$ & 0.014 & $37,131.61$ & 0.012 \\
\hline Jasa Kesehatan dan Kegiatan Sosial & $97,572.55$ & 0.065 & $34,866.72$ & 0.023 \\
\hline Jasa lainnya & $122,934.00$ & 0.102 & $1,866,650.34$ & 1.556 \\
\hline PDB & $25,968,182.27$ & 0.198 & $60,077,814.68$ & 0.458 \\
\hline
\end{tabular}

Sumber: INDEF (2019)

Berdasarkan tabel diatas salah satu yang memiliki dampak besar adalah Jasa keuangan
Berdasarkan data studi INDEF dan Asosiasi Fintech Indonesia penyaluran dana Fintech dan investasi menyumbang output nasional mencapai $\mathrm{Rp}$ 26 triliun. Pada tahun 2019 penyaluran dana dan investasi di Fintech mampu menyumbang sebesar Rp 60 triliun atau meningkat sebesar 130 persen dibandingkan dengan tahun lalu. Hal ini terjadi karena terdapat lonjakan penyaluran dana yang sangat besar di Fintech pada periode 2018-2019. Inovasi keuangan pada bidang Fintech memiliki dampak yang cukup luas terhadap perekonomian Indonesia.

Dampak penyaluran Fintech P2P lending terhadap pertumbuhan ekonomi dapat dilihat pada tabel berikut ini: 
25,3\%. Data ini menunjukkan bahwa keberadaan Fintech justru membuat sektor perbankan mengalami kenaikan, termasuk terkait kerjasama escrow account (penitipan dana) dan virtual account di perbankan umum, sistem pembayaran, hingga credit channeling. Bahkan beberapa bank umum kini telah membentuk modal ventura, sebagai unit untuk melakukan investasi langsung ke perusahaan Fintech. Optimalisasi kerjasama antara Fintech dan perbankan memiliki dampak secara otomatis perbankan ikut menikmati imbal hasil dari pertumbuhan Fintech.

Sementara itu dampak terhadap jasa perusahaan yamg memiliki peran sebagai supporting ekosistem Fintech pun mengalami kenaikan hingga
0,29\%. Jasa perusahaan meliputi bidang IT services, design graphic, HR, business solution, legal, dan coworking spaces.

\section{B. Fintech Lending Terhadap Pendapatan Masyarakat}

Berdasarkan data studi INDEF dan Asosiasi Fintech Indonesia dampak dari adanya investasi yang masuk dalam bidang Fintech dan kegiatan penyaluran dana oleh fintech adalah adanya kenaikan pendapatan faktor produksi. Dampak penyaluran Fintech P2P lending terhadap pendapatan masyarakat dapat dilihat pada tabel berikut ini:

Tabel 2. Dampak Fintech Peer-to-Peer (P2P) Lending Terhadap Pendapatan Masyarakat

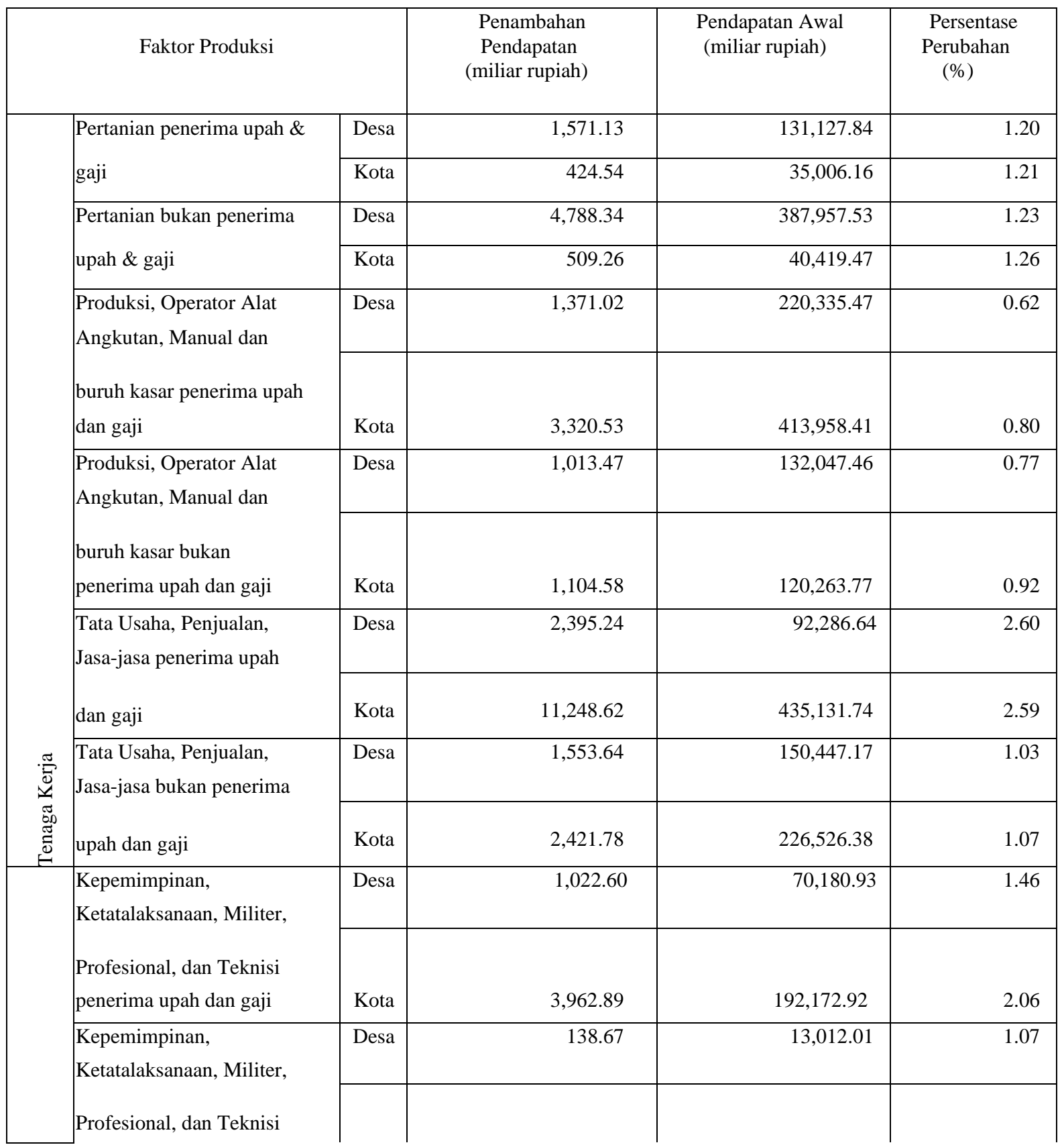




\begin{tabular}{|c|c|c|c|c|}
\hline $\begin{array}{l}\text { bukan penerima upah dan } \\
\text { gaji }\end{array}$ & Kota & 385.07 & $33,451.07$ & 1.15 \\
\hline Bukan Tenaga Kerja & & $43,680.41$ & $2,470,974.96$ & 1.77 \\
\hline Total Faktor Produksi & & $80,911.78$ & $5,165,299.93$ & 1.57 \\
\hline
\end{tabular}

Sumber: INDEF (2019)

Dari tabel diatas dapat dilihat adanya kenaikan pendapatan faktor produksi sebesar 1,57 persen. Kenaikan pendapatan tertinggi di peroleh tenaga kerja golongan tata usaha, penjualan, dan jasa baik di desa dan di kota. Kemudian ada pula tenaga kerja profesional yang bekerja di kota. Kenaikan dari tiga golongan tersebut mencapai lebih dari 2 persen.

Fintech sendiri memang saat ini banyak menyalurkan kepada sektor perdagangan dan menyasar masyarakat pekerja penjualan yang pada umumnya sudah mengenal teknologi ponsel pintar. Maka dari itu sektor tenaga kerja tata usaha, penjualan, dan jasa baik di desa dan di kota memanfaatkan fintech. Selain itu, pemilik modal tata usaha, penjualan, dan jasa baik di desa dan di kota juga mengalami peningkatan pendapatan dengan nominal yang relatif besar.

Pada masyarakat di desa, golongan tenaga kerja yang memiliki manfaat besar akibat adanya investasi yang masuk dalam bidang fintech dan kegiatan penyaluran dana oleh fintech adalah petani dan pengusaha usaha penunjang pertanian. Hal ini sangat didasarkan pada saat ini perusahaan fintech cenderung menyasar kepada sektor ekonomi yang belum terjangkau perbankan seperti sektor pertanian di desa.

\section{Fintech Lending Terhadap Instituti Ekonomi}

Berdasarkan data ilmiah pada studi INDEF dan Asosiasi Fintech Indonesia dampak dari adanya investasi teknologi finansial dan kegiatan penyaluran dana adalah akan mendorong kenaikan pendapatan pada semua institusi ekonomi, Dampak penyaluran Fintech P2P lending terhadap instituti ekonomit dapat dilihat pada tabel berikut ini:

Tabel 3. Dampak Fintech P2P Lending Terhadap Instituti Ekonomi

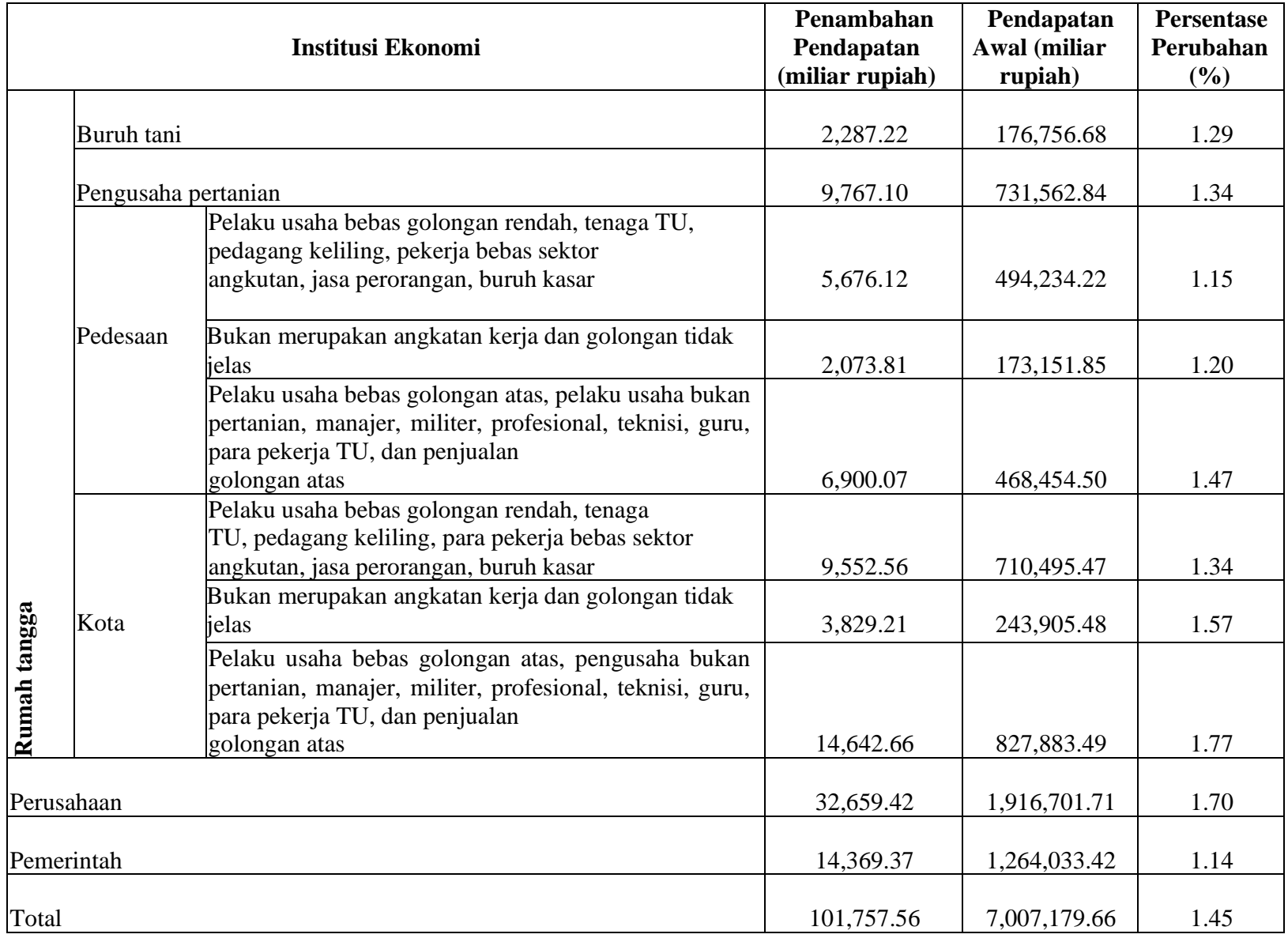

Sumber: INDEF (2019) 
Dari tabel diatas dapat dilihat dampak dari adanya investasi teknologi finansial dan kegiatan penyaluran dana adalah akan mendorong kenaikan pendapatan pada semua institusi ekonomi yakni rumah tangga, perusahaan, dan pemerintah. Secara total, ada kenaikan pendapatan seluruh institusi ekonomi sebesar 1,45 persen atau adanya penambahan pendapatan lebih dari Rp 101,7 miliar. Kenaikan presentase paling tinggi diperoleh dari rumah tangga perkotaan yang termasuk pelaku usaha golongan atas sebesar 1,77 persen. Sedangkan kenaikan presentase yang didapatkan oleh rumah tangga perkotaan yang termasuk pengusaha golongan bawah adalah 1,34 persen. Kenaikan angka yang sama sebesar 1,34 persen, juga didapatkan oleh rumah tangga pengusaha pertanian. Dengan adanya investasi pada sektor Rintech dan kegiatan penyaluran dana, kenaikan yang terjadi lebih banyak dinikmati oleh rumah tangga perkotaan dari berbagai kalangan dan rumah tangga pengusaha pertanian dibandingkan rumah tangga perdesaan.

Sedangkan hasil persentase pada pendapatan perusahaan, dengan adanya kegiatan penyaluran dana dan investasi teknologi finansial, akan membuat kenaikan pendapatan sebesar 1,7 persen atau penambahan pendapatan lebih dari 32,6 miliar rupiah. Sedangkan pada pendapatan pemerintah, adanya kegiatan penyaluran dana dan investasi teknologi finansial akan membuat kenaikan pendapatan sebesar 1,14 persen atau penambahan pendapatan lebih dari 14,3 miliar rupiah.

\section{KESIMPULAN}

Berdasarkan hasil pembahasan dapat disimpulkan bahwa keberadaan Financial Technology (Fintech) memiliki dampak positif dimasa pandemi covid-19. Kontribusi Fintech telah membantu lebih banyak masyarakat yang masih belum terlayani lembaga keuangan formal dalam melakukan transaksi keuangan sesuai dengan kebutuhannya. Pemulihan ekonomi nasional dan peningkatan penerimaan negara dimasa pandemi dapat dilakukan dengan dukungan penguatan regulasi terhadap pertumbuhan Fintech yang inklusif dan berkesinambungan yang memiliki potensi sebagai faktor pemicu lompatan yang sangat besar bagi industri pembayaran layanan keuangan digital. Optimalisasi peran Fintech dalam pemulihan ekonomi nasional perlu dukungan keterlibatan semua pihak yang terkait didalamnya untuk meningkatkan pelayanan keuangan kepada masyarakat luas. Penyaluran pembiayaan melalui Fintech dapat pula dilengkapi dengan dilakukannya proses pendampingan dan pelatihan literasi keuangan. Pelatihan dan pemahaman literasi keuangan akan sangat membantu upaya pemerintah khususnya Otoritas Jasa Keuangan
(OJK) dalam meningkatkan pengetahuan masyarakat terkait sektor finansial sebagai bagian dari upaya untuk meningkatkan kesejahteraan masyarakat.

\section{REFERENSI}

Anwar, K., \& Amri. (2017). Pengaruh Inklusi Keuangan Terhadap PDB Indonesia. Jurnal Ilmiah Mahasiswa Ekonomi Pembangunan, Vol. 2 No., 454-462. Retrieved from http://www.jim.unsyiah.ac.id/EKP/article/view /5719/2404

Awanti, E. (2017). Analisis Pengaruh Inklusi Keuangan Terhadap Stabilitas Sistem Keuangan Di Negara Berkembang Kawasan Asia Tenggara. JIET - Jurnal Ilmu Ekonomi Terapan, Vol. 2 No 2. https://ejournal.unair.ac.id/JIET/article/view/6080 http://dx.doi.org/10.20473/jiet.v2i2.6080

Bank Indonesia. (2020). Booklet Keuangan Inklusif. Retrieved December 28, 2020, from https://www.bi.go.id/id/fungsiutama/stabilitas-sistem-keuangan/keuanganinklusif/Default.aspx

INDEF. (2019). Studi Dampak Fintech P2P Lending terhadap Perekonomian Nasional. Retrieved January $\quad 5, \quad 2021, \quad$ from https://indef.or.id/source/research/Studi Dampak Fintech P2P Lending terhadap Perekonomian Nasional.pdf\%0A\%0A

Katadata. (2020). Januari 2020, Akumulasi Penyaluran Pinjaman Fintech Lending Naik 240\%. Retrieved December 27, 2020, from https://databoks.katadata.co.id/datapublish/202 0/03/12/januari-2020-akumulasi-penyaluranpinjaman-fintech-lending-naik-240\#

Keuangan, O. J. (2020). Statistik Fintech Indonesia. Retrieved December 28, 2020, from https://www.ojk.go.id/id/kanal/iknb/data-danstatistik/fintech/Default.aspx

Maulida, R. (2019). Fintech: Pengertian, Jenis, Hingga Regulasinya di Indonesia. Retrieved from https://www.online-pajak.com/tentangpajak-pribadi/fintech

Muzdalifa, I., Rahma, I. A., \& Novalia, B. G. (2018). Peran Fintech Dalam Meningkatkan Keuangan Inklusif pada UMKM di Indonesia (Pendekatan Keuangan Syariah). Jurnal Masharif AlSyariah: Jurnal Ekonomi Dan Perbankan Syariah, Vol. 3, No.1 http://journal.umsurabaya.ac.id/index.php/Mas/article/view/161 8/0http://dx.doi.org/10.30651/jms.v3i1.1618

Nizar, M. A. (2017). Teknologi Keuangan (Fintech) : Konsep dan Implementasinya di Indonesia. Retrieved January 5, 2021, from 
https://www.researchgate.net

Okaro, C. S. O. (2016). Financial Inclusion and Nigerian Economy (1990-2015). Journal of Policy and Development Studies (JPDS), Vol. 10, No, 4, Page 50-65. Retrieved from https://papers.ssrn.com/sol3/papers.cfm?abstra ct_id=2919965

Peraturan Bank Indonesia tentang Penyelenggaraan Teknologi Finansial. (PBI No.19/12/PBI/2017)
Peraturan Otoritas Jasa Keuangan. Nomor 76/Pojk.07/2016. Tentang. Peningkatan Literasi dan Inklusi Keuangan di Sektor Jasa.

Pratiwi, D. R. (2018). Pentingnya Perkembangan Financial Technology dalam Mendorong Keuangan Inklusif. Buletin APBN. Buletin APBN, III / Edisi 15 Retrieved from https://puskajianggaran.dpr.go.id/produk/detail -buletin-apbn/id/64 
